\title{
Genç Erişkin Bir Hastada İskeletsel Sınıf III Maloklüzyonun Hızlı Üst Çene Genişletme ve Kapaklı Braket Sistemi ile Ortodontik Tedavisi - Bir Olgu Sunumu
}

\author{
Orthodontic Treatment of A Skeletal Class III Malocclusion in A Young Adult Patient \\ With Rapid Maxillary Expansion and Self-Ligating Bracket System - A Case Report
}

Mehmet Ali YAVAN ${ }^{* 1}$ (D)

yavanmehmetali@gmail.com

\author{
Beytullah GÜLSOY ${ }^{1}$ (iD) \\ gulsoybeytullah@hotmail.com
}

Nihal HAMAMCI ${ }^{1}$ (D)

nhamaci@hotmail.com

\begin{abstract}
öz
$\mathrm{Bu}$ olgu sunumunun amacı, büyüme ve gelişimi henüz tamamlanmış, iskeletsel ve dental sınıf III maloklüzyona sahip genç yetişkin bir hastanın kamuflaj tedavisinin sonuçlarını sunmaktır. 13 yaşındaki kadın hasta üst köpek dişlerinin malpozisyonu şikayetiyle kliniğimize başvurmuştur. Klinik incelemede hastada, sirkümmaksiller çapraz kapanıș, çift taraflı sınıf III molar ve kanin ilişki ile artmış overbite tespit edilirken, sefalometrik incelemede kafa kaidesine göre geride bir maksilla, azalmış maksillo-mandibular fark (ANB: -2,8), retrokline alt keserler ve retrüze üst dudak saptanmıștır. Hasta ve ailesi ortodontik yüz maskesi veya ortognatik cerrahi seçeneklerini kabul etmedikleri için çekimsiz kamuflaj tedavisinde karar kılınmıştır. Hastanın maksillasının genişletilerek posterior çapraz kapanışının düzeltilmesi için öncelikle hızlı üst çene genişletme (HÜG) protokolü uygulanmıștır. Genişletme cihazının uzaklaştırılması sonrası düşük torklu kapaklı braket sistemi ile sabit ortodontik tedaviye bașlanmıștır. Bu tedaviyle de anterior çapraz kapanış düzeltilmiş ve üst ve alt çenedeki dişler seviyelenmiş ve hizalanmıştır. Tedaviyle alt keser açları ideal sınırlarda tutularak, üst keser dişlerin yeterli protrüzyonu ve mandibulanın saat yönündeki rotasyonuyla sınıf I dental ve iskeletsel ilişki elde edilmiş ve üst dudakta protrüzyon gözlenmiştir. HÜG ve düşük torklu kapaklı braket sistemiyle sinıf III maloklüzyona sahip vakada iskeletsel, dental ve yumuşak dokuda belirgin iyileşmeler elde edilmiştir.
\end{abstract}

Anahtar Kelimeler: Sınıf III maloklüzyon, Kamuflaj tedavisi, Kapaklı braket

\begin{abstract}
The aim of this case report was to present the results of a camouflage treatment in a young adult patient with skeletal and dental Class III malocclusion. A 13-year old female patient referred to our clinic with with a chief complaint of upper canine malposition. In clinical examination, increased overbite with circummaxillary cross-bite, bilateral class III molar and canine relationships were detected. Cephalometric examination revealed a retruded maxillary complex, decreased maxillo-mandibular difference (ANB: -2.8), retroclined lower incisors, and retruded upper lip. Since the patient and her family did not accept orthodontic face mask or orthognathic surgery options, the final decision was camouflage treatment without extraction. In order to correct the posterior cross-bite, the rapid maxillary expansion (RME) protocol was applied. After the expansion device was removed, fixed orthodontic treatment was started with a low-torque self-ligating bracket system. With this treatment, the anterior cross bite was corrected, and the upper and lower teeth were leveled and aligned. Class I dental and skeletal relationships were achieved through adequate protrusion of the upper incisors and clockwise rotation of the mandible while keeping the lower incisor angles within ideal limits, and protrusion was observed in the upper lip. Significant improvements were achieved in skeletal, dental and soft tissues of the case with class III malocclusion with the RME and low torque self-ligating bracket system.
\end{abstract}

Keywords: Class III malocclusion, Camouflage treatment, Self-ligating bracket 


\section{GíRIş}

Sınıf III maloklüzyonlar ortodonti kliniklerinde teşhis ve tedavi planlanması açısından en kompleks maloklüzyonlardan biridir. ${ }^{1}$ İskeletsel sınıf III maloklüzyonlar; mandibular büyüklük, mandibular prognati, maksiller boyut yetersizliği, maksiller retrognati veya bunların kombinasyonu kaynaklı olabilir. ${ }^{2,3}$ Ellis ve McNamara, yaptıkları araştırmada retrognatik maksillanın, sınıf III maloklüzyonların \% 65 67'sini oluşturduğunu tespit etmişlerdir. ${ }^{4}$

İskeletsel sınıf III maloklüzyonların tedavi seçeneklerine karar verirken maloklüzyonun hangi çeneden kaynaklandığı iyi analiz edilmelidir. Maksiller retrüzyon kaynaklı ve büyüme gelişim dönemindeki sınıf III hastalar, ortopedik tedavi ile maksillanın büyümesi yönlendirilerek tedavi edilebilmektedir. ${ }^{5-8}$

Büyüme gelişimi tamamlanmış hastalarda, ortopedik tedavi yerine kamuflaj ya da ortognatik cerrahi tercih edilmektedir. Son ylllarda geçici ankraj üniteleri ile hızlı üst çene genişletme (HÜG) aygitlarının kombinasyonuyla, genç erişkinlerde de iskeletsel olarak maksillada anlamlı genişlemeler bildirilmiştir. ${ }^{9,10}$ Maloklüzyon hafif veya orta şiddette ve hastanın yüz estetiği görece kabul edilebilir ise kamuflaj tedavisi düşünülürken, şiddetli iskeletsel sinıf III maloklüzyonlarda ortognatik cerrahi tercih edilmektedir. ${ }^{11}$ Kamuflaj tedavisinde amaç, hastanın iskeletsel uyumsuzluğunu dentoalveolar kompanzasyonu yönlendirerek kabul edilebilir bir okluzyon, estetik ve fonksiyon sağlamaktır. ${ }^{12,13}$
Bu vaka raporunun amacl, büyüme ve gelişimi henüz bitmiş iskeletsel ve dental sınıf III maloklüzyona sahip genç yetişkin bir hastanın HÜG ve low tork kapaklı braket sistemi kullanılarak sabit ortodontik tedaviyle yapılan kamuflaj tedavisinin sonuçlarını sunmaktır.

\section{OLGU SUNUMU}

Adıyaman Üniversitesi, Diş Hekimliği Fakültesi, Ortodonti Anabilim Dalı'na üst köpek dişlerinin yukarıda, üst dişlerinin geride ve alt çenesinin ileride olması şikayetiyle başvuran kronolojik yaşı 13 yıl olan kadin hastada, $3 \mathrm{~mm}$ negatif overjet ve $4 \mathrm{~mm}$ overbite görülmüștür. Klinik incelemede hastanın, profilinin görece düz, alt dudağının önde, ağız içinde çift taraflı sınıf III ilişkiye ve posterior çapraz kapanışa sahip olduğu tespit edilmiştir. Üst çenede dental orta hat yüz orta hattıyla çakıșırken, mandibular orta hat $2 \mathrm{~mm}$ sola kaymıștır (Resim 1). Hayes Nance model analizi, maksillada $17 \mathrm{~mm}$, mandibulada ise $3 \mathrm{~mm}$ yer ihtiyacı olduğunu göstermiştir. Spee eğrisi derinliğinin ise 3,2 mm olduğu saptanmıștır. Sefalometrik değerler, maksiller retrognati (SNA: 75,7 ${ }^{\circ}$ ) kaynaklı sınıf III maloklüzyona (ANB: $-2,8^{\circ}$ ) işaret etmiştir. Hastanın vertikal olarak yüksek açıya yatkın bir paterne sahip olduğu (SN/GoGn: 36,4 ) görülmüștür. Üst keser dişleri normal sinırlarda (U1/SN: $103,1^{\circ}$ ), mandibular dişleri ise retruzivdir (IMPA: $83^{\circ}$ ). El bilek filmi değerlendirildiğinde ise hastanın büyüme gelişiminin sonunda olduğu (Radius union) görülmüştür (Resim 2).

Resim 1: Hastanın tedavi öncesi ağız dışı ve ağız içi fotoğrafları
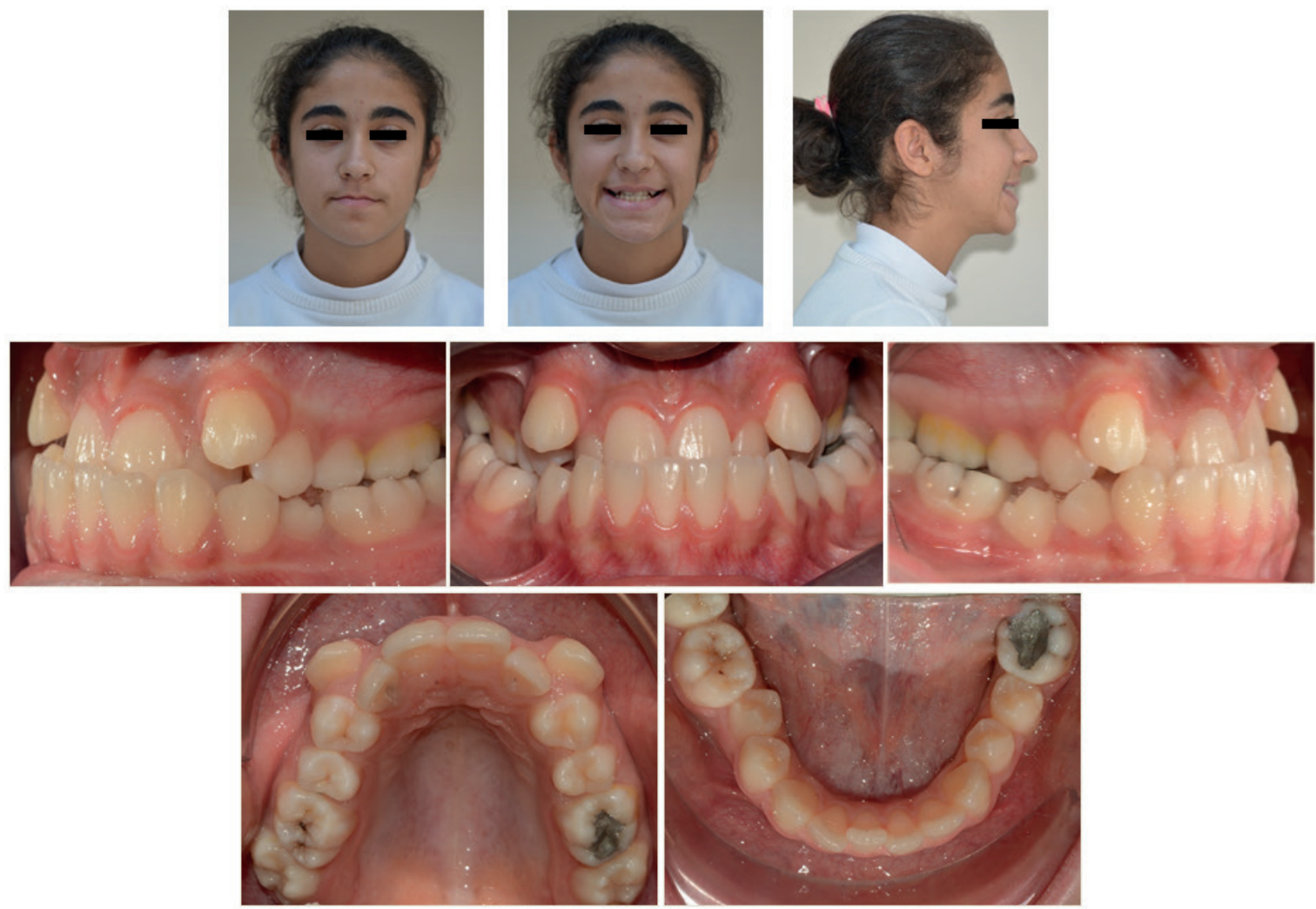


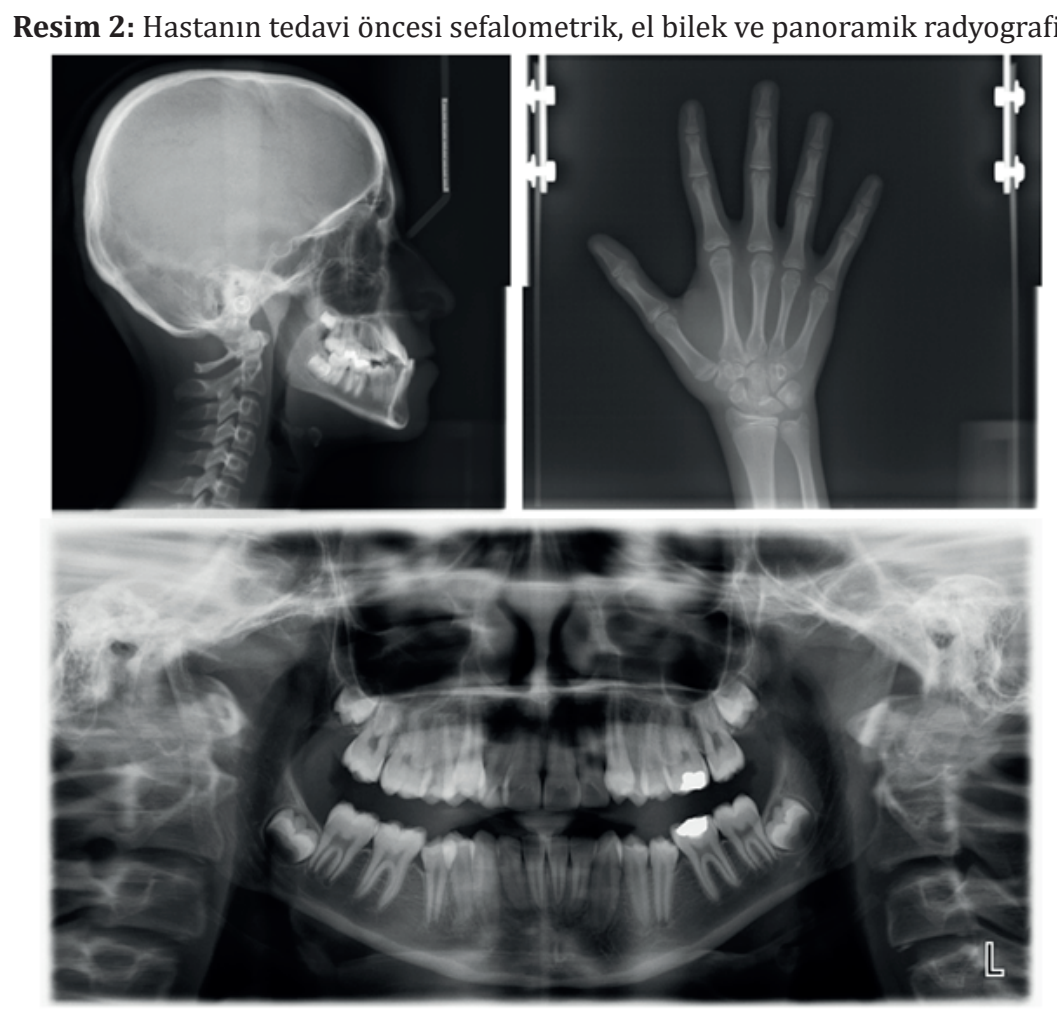

Üç adet tedavi seçeneği hastaya sunulmuştur. Bunlar; yüz maskesi tedavisi, ortognatik cerrahi ve çekimli/ çekimsiz kamuflaj tedavisi. Hasta ve ailesi yüz maskesi ve ortognatik cerrahi seçeneklerini kabul etmedikleri için kamuflaj tedavisinde karar kılınmıștır. Hastanın düz bir profile, retruziv alt keserlere, transversal olarak dar bir maksillaya ve üst çenesinde 17 mm lik yer darlığına sahip olması sebebiyle önce HÜG sonrasında da low tork kapaklı braket sistemi (Damon Q Ormco, Calif, USA) ile tedavi edilmesine karar verilmiştir.

Hastanın maksillasındaki posterior çapraz kapanış nedeniyle sabit tedavi mekanikleri öncesi HÜG işlemi uygulanmıştır. Öncelikle hastaya rijit akrilik bonded HÜG apareyi uygulanmış ardından sabit ortodontik mekaniklerle tedavisi tamamlanmıștır. HÜG apareyi simante edildikten sonra hastaya apareyin ilk hafta günde 2 tur, sonrasında ise günde 1 tur çevirtilerek maksillasının genişletilmesine başlanmıştır. 4 hafta sonunda çevirme protokolü tamamlanmış ve apareyin vidası dönmemesi için sabitlenmiş bu şekilde 3 ay stabilizasyon için beklenmiştir. 3 ay sonunda aparey sökülüp dişler temizlenmiş 6 numaralı dişlere retansiyon amaçlı transplatal ark (TPA) yapılmıştır. TPA'nın kolları 4 ve 5 numaralı dişlerin palatinaline değecek şekilde uzatılmış ve aynı seans 22 slot low tork Damon Q braket sistemi önce üst çeneye altı ay sonra ise alt çeneye uygulanmıştır. Alt çene için altı ay bekleme süresinin sebebi, alt kesicilerin erken dönemde protrüzyonunun önüne geçerek, üst çene genişletme ve sabit tedaviyle altı aylık süreçte elde edilen pozitif overjetin devamını sağlamaktır.
Sirasiyla $0.013,0.016,0.014 \times 0.025$ inch boyutlu Cu-NiTi teller (Ormco, Calif, USA) ile dişler seviyelenmiş ve $0.016 \times 0.022$ paslanmaz çelik tel üzerinde high vestibuldeki maksiller kanin dişler için open coiller ile yer açılmıştır. Daha sonra yardımcı arklar ile kanin dişler ideal pozisyonlarına alınmıștır. Alt çenede de aynı sırayla yuvarlak ve köșeli arklarla seviyeleme ve hizalanma yapılırken, alt anterior dişlere interproksimal mine aşındırma uygulaması yapılmıştır. Son aşamada alt ve üst arklara 0,017 × 0,025 inch paslanmaz çelik teller yerleştirilmiş finishing aşaması tamamlanmıştır.

Toplam 25 aylık tedavi sonunda arzu edilen sonuçlara ulaşılmış ve braketler sökülerek, tedavinin retansiyonu için alt ve üst lingual retainer (Penta one, .0195 ”) ve ilk 6 ay tüm gün daha sonra sadece geceleri kullanması için koruyucu essix plaklar yapılmıștır.

Yapılan ortodontik kamuflaj tedavisi sonucunda üst çenede transversal darlık düzeltilmiş, maksiller kanin dişler ark üzerinde yerlerine alınmıș, orta hat sapması düzeltilmiş ve kanin ve molar ilișkinin sınıf I olması sağlanmıștır (Resim 3). İskeletsel ölçümlerde hastanın dik yön boyutlarında artış (SN/GoGn: $1,2^{\circ}$ lik artış) görülmüştür. ANB açısında $2,9^{\circ}$ lik artış gözlenmiştir. Bunun yanında U1-SN açısında 11,9, konveksite açısında ise $5,5^{\circ}$ lik artış görülmüştür. Overjet ölçümünde $5,1 \mathrm{~mm}$ artış görülürken, Spee eğrisi derinliğinde $2,7 \mathrm{~mm}$, overbite ölçümünde ise 4 mm lik azalma kaydedilmiştir (Resim 4). Tedavi başlangıcı (T0) ve tedavi bitimi (T1), dental ve yumuşak doku parametrelerindeki değişimler Tablo 1'de gösterilmiștir. 
Resim 3: Hastanın tedavi sonrası ağız dıșı ve ağız içi fotoğrafları
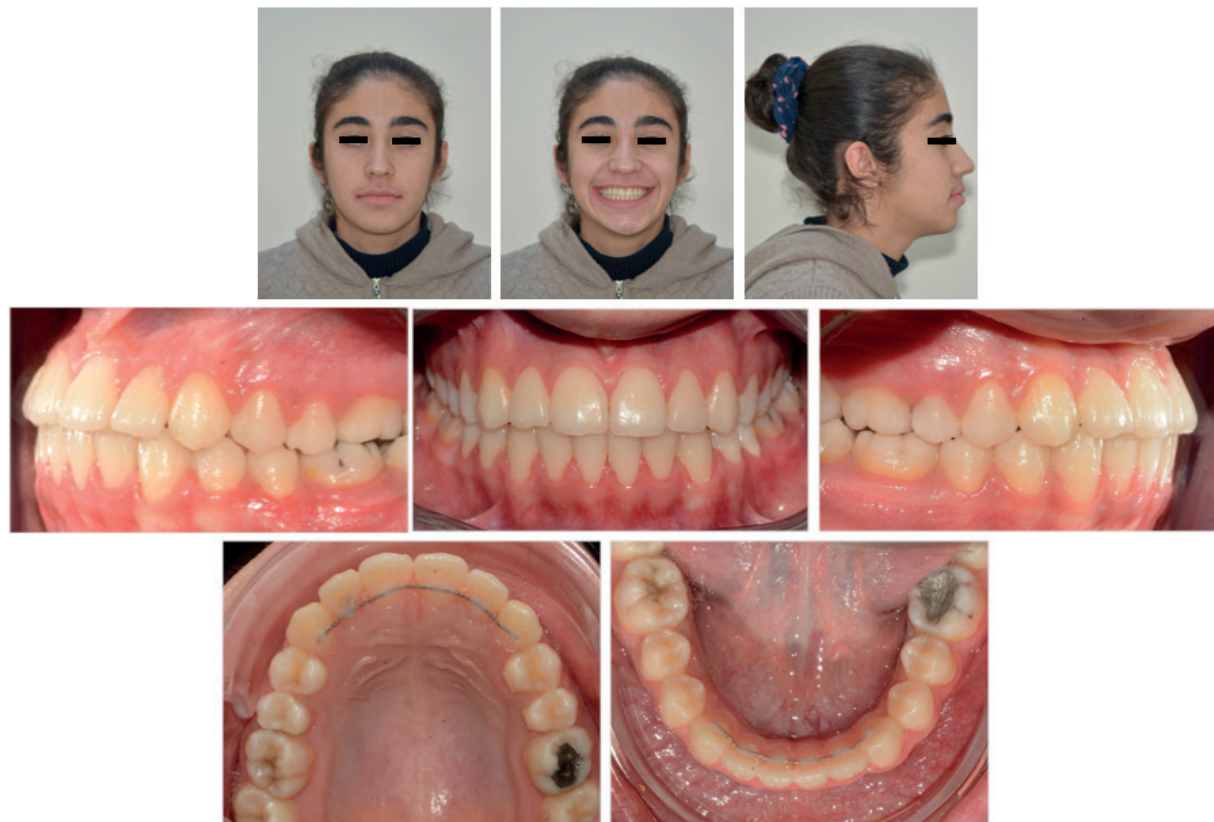

Resim 4: Hastanın tedavi sonrası sefalometrik ve panoramik radyografileri
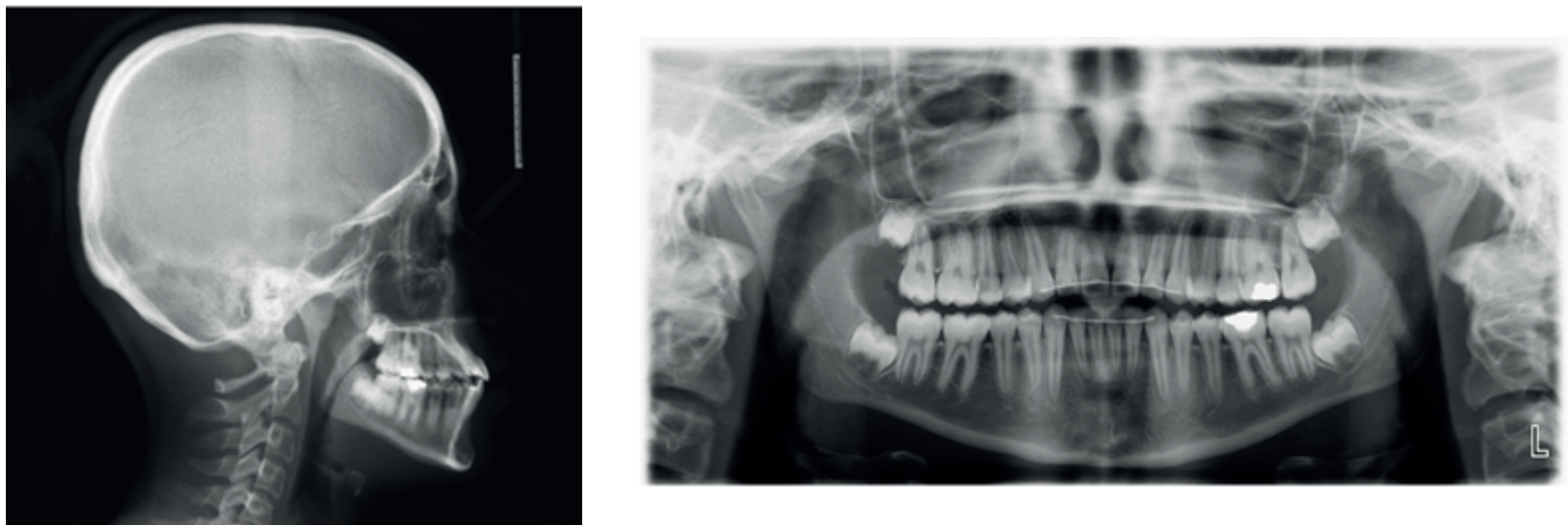

Tablo 1: Tedavi öncesi (T0) ve sonrası (T1) iskeletsel parametreler, dental parametreler ve yumuşak doku parametrelerindeki değişimler

\begin{tabular}{|c|c|c|}
\hline Ölçümler & T0 & T1 \\
\hline SNA $\left(^{\circ}\right)$ & 75.7 & 76.8 \\
\hline $\operatorname{SNB}\left({ }^{\circ}\right)$ & 78.5 & 76.7 \\
\hline $\operatorname{ANB}\left({ }^{\circ}\right)$ & -2.8 & 0.1 \\
\hline SN-GoGn $\left(^{\circ}\right)$ & 36.4 & 37.6 \\
\hline $\mathrm{U} 1 / \mathrm{SN}\left({ }^{\circ}\right)$ & 103.1 & 115 \\
\hline $\operatorname{IMPA}\left({ }^{\circ}\right)$ & 83 & 93 \\
\hline $\mathrm{UL}-\mathrm{E}(\mathrm{mm})$ & -5 & -2 \\
\hline LL-E (mm) & -1 & 2 \\
\hline Overjet (mm) & -3 & 2.1 \\
\hline Overbite $(\mathrm{mm})$ & 4.3 & 0.3 \\
\hline Spee eğrisi derinliği (mm) & 3.2 & 0.5 \\
\hline
\end{tabular}

SNA ( ${ }^{\circ}$ ): Sella, Nasion ve A noktaları arasındaki açı, SNB $\left({ }^{\circ}\right)$ : Sella, Nasion ve B noktaları arasındaki açı, ANB $\left({ }^{\circ}\right)$ : Nasion, A ve B noktaları arasındaki açı, SN/GoGn $\left({ }^{\circ}\right)$ : SN ile GoGn düzlemleri arasındaki açı. U1-SN $\left({ }^{\circ}\right)$ : Sella-Nasion düzlemi ile Üst keser uzun ekseni arasındaki açı. IMPA $\left({ }^{\circ}\right):$ Alt en ileri kesici dișin uzun ekseninin mandibular düzlemi ile yaptığı açı. UL-E (mm): Üst dudağın sagital düzlemdeki en ileri noktasının Ricketts'in Estetik Düzlemine (E) olan dik mesafesi. LL-E (mm): Alt dudağın sagital düzlemdeki en ileri noktasının Ricketts'in Estetik Düzlemine (E) olan dik mesafesi. Overjet (mm): Üst en ileri orta kesici dișin vestibul kenarı ile alt en ileri orta kesici dișin vestibül yüzeyi arasında kalan sagital yöndeki mesafe. Overbite (mm): Üst ve alt en ileri orta kesici dişlerin kesici kenarları arasındaki vertikal yöndeki kapanış fazlalığı. 


\section{TARTIŞMA VE SONUÇ}

Maksillanın yetersizliğine bağlı iskeletsel sınıf III maloklüzyonlu hastaların çocukluk ve ergenlik dönemlerinde yüz maskesi ile tedavisi etkili bir tedavi șeklidir. ${ }^{6}$ Erişkin veya koopere olmayan bireylerde ise yüz maskesi kullanılamayacağından tedavi seçeneği olarak geriye kamuflaj veya ortognatik cerrahi kalmaktadır. ${ }^{11}$ Ancak, ortognatik tedavi seçeneği, hasta ve hasta yakınları tarafından cerrahi riskler, yüksek maliyet, komplikasyonlar ve korku gibi nedenlerden dolayı sıklıkla kabul edilmemektedir. ${ }^{14}$ Bununla birlikte kamuflaj tedavisi ile üst kesici dişlerin proklinasyonu, alt kesici dişlerin retrüzyonu, alt çenenin aşağı ve geri yönde rotasyonu ile sınıf III maloklüzyonun tedavisi mümkün olmaktadır. ${ }^{15}$ Kerr ve arkadaşları tedavi seçeneğine karar verirken iskeletsel sınıf III maloklüzyona sahip erișkin bireylerde ANB açısı $-4^{\circ}$ den, IMPA $83^{\circ}$ 'den küçük ise tedavinin ortognatik cerrahi olması gerektiğini belirtmişlerdir. ${ }^{16}$ $\mathrm{Bu}$ vaka raporu, Kerr ve arkadaşlarının belirttiği sınırlar içinde olduğu için ve hasta ortognatik cerrahiyi ve yüz maskesini tercih etmediği için kendisinin ve ebeveyninin onayı alınarak 2 aşamalı (HÜG ve low tork Damon braketler ile sabit ortodontik tedavi) çekimsiz kamuflaj tedavi yaklaşımı ile hastamız tedavi edilmiştir.

Literatürde üst çene genișletmesinin maksillanın öne doğru hareketini sağladığı birçok çalıșmayla ortaya konmaktadır., ${ }^{517-20}$ Sarı ve ark. ortalama yaşı 12,7 olan, daimi dişlenme dönemindeki 17 hastaya olgu raporumuzdaki gibi akrilik splint tip HÜG aygıtı uygulamışlar ve genişletme protokolünden hemen sonra maksillada anlamlı ilerleme $\left(\mathrm{SNA}^{\circ}\right.$ : $\left.+1,44^{\circ}\right)$ kaydetmişlerdir. ${ }^{19}$ Doruk ve ark. da HÜG protokolü ile SNA açısında $+2,12^{\circ}$ lik anlamlı bir artış rapor etmişlerdir. ${ }^{20} \mathrm{Bu}$ vakada da hastanın hem transversal darlığını çözmek hem de maksillanın bir miktar öne hareketini sağlamak için HÜG apareyi kullanılmıștır. Vakamızda tedavi sonrasında, SNA açısındaki $1,1^{\circ}$ lik artışın literatürdeki bulgularla uyum içinde olduğu görülmektedir.

Damon braket sistemi, herhangi bir ligatür işlemi gerektirmeyen kapaklı braket adı verilen bir sistemdir. Bu braketlerin slotu 4 sert duvardan oluşur. Bu sayede daha düşük bir sürtünme ve maksimum kontrol sağladığı bildirilmiştir. ${ }^{21}$ Üretici firma, braketlerin düzgün konturu ve yuvarlatılmış kenarları sayesinde hasta konforunu sayesinde hasta konforunu artırdığını iddia etmektedir. Ayrıca koltuk zamanını, randevu sayısını ve toplam tedavi süresini kısaltabildiği bildirilmiștir. ${ }^{22}$ Damon braket sistemi ark genişliğini arttırmada başarılı bir sistem olduğundan diş çekimi içermeyen orta şiddette çapraşıklık vakalarında başarılı bir şekilde kullanılmaktadir. ${ }^{23} \mathrm{Bu}$ vakada sabit ortodontik tedavi için low tork Damon braket sisteminin kullanılmasının sebebi üst çenedeki çapraşılılı̆̆ı 5 mm'den fazla olması, maksiller anterior dişlerin daha fazla prokline olmasını istemememiz, üst arkın daralmış yapısı ve tedavi süresini minimuma indirmek isteyișimizdir. Bu vakada; üst arktaki aşırı çapraşıklık diş çekimi gerekmeden ve maksillar retrüzyon, ortognatik cerrahiye gerek kalmadan elimine edilebilmiştir.

İskeletsel sınıf III maloklüzyonlarda anomalinin tedavisi için başvuran hastaların birçoğunda kompanzasyon mekanizmasının çalışmış olduğu yani alt keserlerinin retrüziv, üst keserlerinin ise protrüziv olduğu görülmektedir. ${ }^{11,24} \mathrm{Bu}$ durum negatif overjetin kamuflaj yöntemi ile düzeltilirken, halihazırda protrüziv olan üst keserlerin daha fazla protrüze edileceği, retrüziv olan alt keserlerin ise daha fazla retrakte edileceği anlamını taşımaktadır. ${ }^{11,24}$ Hastamızın üst keserleri başlangıçta normal sınırlara yakınken, alt keserlerinin retrüziv olduğu göze çarpmaktadır. Derin Spee eğrisinin farklı iskeletsel maloklüzyon tiplerindeki karakteristiğinin araştırıldığı bir çalışmada $^{25}$, Spee eğrisinin sinıf III paternde alt keserlerin linguoversiyonu ile ve hiperdiverjan paternde alt keser ve köpek dişlerin extrüzyonuyla birlikte alt keserlerin linguoversiyonu ile karakterize olduğu rapor edilmiştir. Başlangıçta 3,2 mm Spee derinliğine sahip olan sınıf III hiperdiverjan eğiliminde olan hastamız tedavi bașında benzer șekilde ekstrüze alt anterior dişler ve retrokline alt keser dișlere sahipti. Tedavi ile alt keser inklinasyonlarındaki iyileșmelere ek olarak Spee derinliğinde de belirgin bir azalma gözlemlendi.

Overjetin düzeltilmesi esnasında alt keserlerin daha çok retrüze olmaması için hastamızda alt premolar çekimi planlanmamıştır. Hastamızda anomalinin kamufle edilmesi için geriye kalan tek yol, alt çenenin saat yönünde rotasyonu ve üst keserlerin protrüze edilmesidir. Hastanın başlangıçtaki görece artmış overbiteı $(4,3 \mathrm{~mm})$ tedavi planlamamızda avantaj sağlamıştır. Mandibulanın saat yönünde rotasyonuyla birlikte overbite değerinde tedavi bitiminde (4 mm) ciddi bir azalma görülmüştür. Bu azalmada, mandibulanın saat yönünde rotasyonu ile birlikte alt ve üst keserlerin protrüze edilmesi, posterior dişlerin ektrüze edilmesi ve braket pozisyonlandırılmasının da etkili olduğu düşünülmektedir. ${ }^{26}$ Literatürde, HÜG protokolünün, maksiller molarların bukkale devrilmesine ve prematür kontaklara sebep olabildiği; sonuç olarak da mandibulada olgu sunumumuzla uyumlu olarak saat yönünde anlamlı rotasyona sebep olduğu bildirilmiştir. ${ }^{27-29}$

Üst keserlerin protrüzyon ve proklinasyonunun minimize edilmesi için ise low tork braketler kullanılmıştır. Bu braketler standart torklu braketlere göre maksiller ve mandibular keserlerde azaltılmış tork açıları içermektedir. Sonuç olarak $17 \mathrm{~mm}$ lik yer darlığı olan hastamızda, HÜG ve 11,9 lik kabul edilebilir 
bir proklinasyon ile negatif overjet düzeltilmiştir.

Sınıf III kamuflaj tedavisini sadece estetik amaçlı yapmadığımızı hastanın diş ve ağız yapısının sağlı̆̆ını da korumamız gerektiğini unutmamalıyız. Bu yüzden kök rezorbsiyonunu önlemek ya da en aza indirmek için diş çevresi dokularının limitlerini așmamak çok önemlidir. Burns ve arkadaşları sınıf III kamuflaj tedavisinde IMPA alt sınırının $80^{\circ}$, U1-SN değerinin üst sınırının ise $120^{\circ}$ olması gerektiğini bildirmektedir. ${ }^{14}$ Tablo 1'de, vakanın bahsedilen üst ve alt keser açılarının sınırları dahilinde olduğu görülmektedir.

HÜG ve low tork kapaklı braket sistemi ile iskeletsel sınıf III maloklüzyonunun tedavisini paylaștığımız vakanın limitasyonları arasında, raporun kısa dönem sonuçlarını içermesi ve detaylı kök ve alveol incelemesine izin veremeyen iki boyutlu radyografilerle sonuçların değerlendirilmesinin yapılmasıdır. Gelecekteki vaka raporlarında üç boyutlu değerlendirmeyle, bu yöntemin yan etkileri değerlendirilebilir ve yöntemin uzun vadeli sonuçları gözlemlenebilir.

Genç erişkin bir hastaya kamuflaj tedavisi ile iyileştirilmiş bir oklüzyon, fonksiyon ve estetik kazandırılmıştır. Tedavi sonrasında alt ve üst dişlerin açları olması gereken sınırlar içerisindedir. Yüz maskesi kullanmayı veya ortognatik cerrahiyi arzu etmeyen genç yetişkinlerde, alt premolar çekimi de endike değilse low tork kapaklı braket sistemi tedavi seçeneği olarak düșünülebilir.

\section{Bilgilendirilmiş Onam}

Hasta ve ebeveyninden bilgilendirilmiş onam formu alınmıştır.

\section{KAYNAKLAR}

1. Janson G, Souza JEPD, Barros SEC, Andrade Junior P, Nakamura AY. Orthodontic treatment alternative to a Class III subdivision malocclusion. J Appl Oral Sci. 2009;17:354-363.

2. Çelikoğlu M, Kiki A, Oktay H. İskeletsel Sınıf III Malokluzonun Erken Dönem Tedavisi (Vaka Raporu). J Fac Dent Ataturk Uni. 2009;2009:192-197.

3. Williams S, Aarhus CA. The morphology of the potential Class III skeletal pattern in the growing child. Am J Orthod. 1986;89:302-311.

4. Ellis E, McNamara JA. Components of adult Class III malocclusion. Am J Oral Maxillofac Surg. 1984;42(5):295-305.

5. Halıcıoğlu K, Yavuz İ. Literatür derlemesi: üst çene genişletmesinde apareyler ve felsefeler. J Fac Dent Ataturk Uni 2011:32-39.

6. Yavuz İ, Halicioglu K, Ceylan İ, Dagsuyu IM, Erdem A. The effects of face mask therapy with and without rapid maxillary expansion in adolescent patients. Aust Orthod J. 2012;28:63.

7. Vaughn GA, Mason B, Moon H-B, Turley PK. The effects of maxillary protraction therapy with or without rapid palatal expansion: a prospective, randomized clinical trial. Am J Orthod Dentofacial Orthop. 2005;128:299-309.

8. Ngan P, Yiu C, Hu A, Hägg U, Wei SH, Gunel E. Cephalometric and occlusal changes following maxillary expansion and protraction. Eur J Orthod. 1998;20:237254.

9. Calil RC, Ramirez CMM, Otazu A, et al. Maxillary dental and skeletal effects after treatment with self-ligating appliance and miniscrew-assisted rapid maxillary expansion. Am J Orthod Dentofacial Orthop. 2020.

10. Brunetto DP, Sant'Anna EF, Machado AW, Moon W. Non-surgical treatment of transverse deficiency in adults using Microimplant-assisted Rapid Palatal Expansion (MARPE). Dental Press J Orthod. 2017;22(1):110-125.

11. Troy BA, Shanker S, Fields HW, Vig K, Johnston W. Comparison of incisor inclination in patients with Class III malocclusion treated with orthognathic surgery or orthodontic camouflage. Am J Orthod Dentofacial Orthop. 2009;135:146. e141-146. e149.

12. Schoenwetter R. Nonsurgical class iii orthodontic treatment. Angle Orthod. 1977;47:147-155.

13. Lin J, Gu Y. Preliminary investigation of nonsurgical treatment of severe skeletal Class III malocclusion in the permanent dentition. Angle Orthod. 2003;73:401410.

14. Burns NR, Musich DR, Martin C, Razmus T, Gunel E, Ngan P. Class III camouflage treatment: what are the limits? Am J Orthod Dentofacial Orthop. 2010;137:9. e1-9. e13.

15. Rabie A-BM, Wong RW, Min G. Treatment in borderline Class III malocclusion: orthodontic camouflage (extraction) versus orthognathic surgery. Open Dent J. 2008;2:38.

16. Kerr W, Miller S, Dawber J. Class III malocclusion: surgery or orthodontics? Br J Orthod. 1992;19:21-24.

17. Hamamcı N, Başaran G, Sahin S. Nonsurgical correction of an adult skeletal class III and open-bite malocclusion. Angle Orthod. 2006;76:527-532.

18. Basciftci F, Karaman A. Effects of a modified acrylic bonded rapid maxillary expansion appliance and vertical chin cap on dentofacial structures. Angle Orthod. 2002;72:61-71.

19. Sari Z, Uysal T, Usumez S, Basciftci FA. Rapid maxillary expansion. Is it better in the mixed or in the permanent dentition? Angle Orthod. 2003;73:654-661.

20. Doruk C, Bicakci AA, Basciftci FA, Agar U, Babacan H. A comparison of the effects of rapid maxillary expansion and fan-type rapid maxillary expansion on dentofacial structures. Angle Orthod. 2004;74:184-194.

21. Gökçelik A, Polat Ö. Ortodontik braket teknolojisindeki son yenilik: Selfligating braketler. Turk J Orthod. 2007;20:71-81.

22. Tagawa D. The Damon system vs. conventional appliances: a comparative study. Clin Impressions. 2006;15(1):4-9.

23. Yi-li Y, Guo-hua T, Fang-fang G, Lin-ling C, Yu-fen Q. A comparison of rapid palatal expansion and Damon appliance on non-extraction correction of dental crowding. Shanghai Kou Qiang Yi Xue. 2008;17.

24. Ellis III E, McNamara Jr JA. Components of adult Class 
III open-bite malocclusion. Am J Orthod. 1984;86:277290.

25. Akbulut AS, Kim KA. Farklı iskeletsel maloklüzyon tiplerinde derin Spee eğrisinin dentoiskeletsel karakteristiği. Acta Odontol Turc 2019;36(3):73-80

26. Coban G, Öztürk T, Türker G. Ortodontik tedavilerde kullanılan farklı kesici diș intrüzyon mekaniklerinin değerlendirilmesi. Mersin Üniversitesi Sağlık Bilimleri Dergisi.13(3):318-330.

27. Yavan MA, Kaya S, Kervancioglu P, Kocahan S. Evaluation of effects of a modified asymmetric rapid maxillary expansion appliance on the upper airway volume by cone beam computed tomography. J Dent Sci. 2020;16(1):58-64.

28. Ramoglu SI, Sari Z. Maxillary expansion in the mixed dentition: rapid or semi-rapid? Eur J Orthod. 2010;32(1):11-18.

29. Chung C-H, Font B. Skeletal and dental changes in the sagittal, vertical, and transverse dimensions after rapid palatal expansion. Am J Orthod Dentofacial Orthop. 2004;126(5):569-575. 